\title{
Influence of different water deficit levels during grain filling on yield and total polyphenols content in spring wheat cultivars
}

\author{
Carlos Fuentealba-Sandoval $^{1,2}$, Alberto Pedreros ${ }^{1 *}$, Susana Fischer ${ }^{1}$, and María Dolores López ${ }^{1}$ \\ ${ }^{1}$ Universidad de Concepción, Facultad de Agronomía, Av. Vicente Méndez 595, Chillán, Chile. \\ *Corresponding author (jpedrerosl@udec.cl). \\ ${ }^{2}$ Universidad de Concepción, Programa de Magister en Ciencias Agronómicas, Av. Vicente Méndez 595, Chillán, Chile.
}

Received: 20 March 2020; Accepted: 22 May 2020; doi:10.4067/S0718-58392020000300433

\begin{abstract}
Wheat (Triticum aestivum L.) is often affected by abiotic stress such as high temperatures and water deficit. Due to this, grain yield can be reduced by a water deficit and an inadequate grain filling as well as affect synthesis of polyphenolic compounds. The aim of this study was to determine the influence of water deficit on yield in spring wheat cultivars during grain filling stage, and evaluate total polyphenol content in whole wheat flour. Experiments were conducted at two locations during 2016-2017 growing season, using a randomized complete block design with a split-plot arrangement, with 12 treatments consisting of three irrigations levels and four spring wheat cultivars. In Site 1, interaction $(\mathrm{P}<0.05)$ was obtained between water deficit level and cultivar, 'Pantera-INIA CL' achieved highest grain yield $\left(10.5 \mathrm{Mg} \mathrm{ha}^{-1}\right)$, with a well-watered treatment, while 'Lasana' reached lowest grain yield $\left(8.5 \mathrm{Mg} \mathrm{ha}^{-1}\right)$, with a severe water deficit. However, water deficit did not affect significantly $(\mathrm{P}>0.05)$ grain yield in Site 2, and differences were observed only between cultivars $(\mathrm{P}<0.05)$ in a range of 6.1 to $7.1 \mathrm{Mg} \mathrm{ha}^{-1}$. Total polyphenol content was not affected by water deficit, differences were only observed between cultivars in both locations $(\mathrm{P}<0.05)$. However, cultivars showed a higher total polyphenol content in Site 1. Water deficit level did not negatively influence yield of four wheat cultivars evaluated in Site 2. While in Site 1, only yield of 'Lasana' and 'Pantera-INIA CL' was reduced, with severe water deficit.
\end{abstract}

Key words: Antioxidants, bread wheat, cereal production, irrigation, terminal drought, Triticum aestivum.

\section{INTRODUCTION}

Wheat (Triticum aestivum L.) is one of the three major cereals and it is used for a wide range of food products such as bread, cookies, cakes, and noodles (Shewry, 2018). In fact, bread wheat is one of most important crops cultivated into the world; with a current production of $~ 772$ million tons per year (FAO, 2017), and it is the third largest crop in production and the first in surface globally. It is an essential source of calories in human diets, providing with other cereals about $60 \%$ of the daily caloric intake, being of primary importance to ensure food security (Shewry, 2018). On average, wheat provides about $20 \%$ of the daily calories and protein per capita worldwide (Hawkesford et al., 2013). Additionally, it also serves as an important source of vitamins, minerals and antioxidants (Kim and Kim, 2017). In Chile, is the most important cultivated crop in terms of sown area (Engler and del Pozo, 2013) reaching approximately 225042 ha in the 2016-2017 season, $92 \%$ of them corresponded to bread wheat, with estimated production of 1.5 million tons (ODEPA, 2017). In this context, the south-central area (from Nuble to La Araucanía Regions) represents about $86 \%$ of national planting, with an area that in recent years has fluctuated around 176000 ha (ODEPA, 2017). 
During the grain filling stage, this crop is often affected by abiotic stress such as high temperatures and water stress in the different environments (Lizana and Calderini, 2013; Mäkinen et al., 2018). Due to this, grain yield in wheat can be reduced by a water deficit and an inadequate grain filling (Hernandez et al., 2015; García et al., 2016) as well as affect the synthesis of polyphenolic compounds in wheat and its derivatives rich in antioxidants. Phenolic acids, such as ferulic, syringic, p-coumaric, vanillic, and caffeic acids, are natural antioxidants found in wheat grain (Poutanen, 2012), which are known as powerful antioxidants. The highest concentrations of these compounds are found in the outer layers of the grain which constitute the bran or pericarp (Poutanen, 2012). Therefore, wheats with high content of antioxidants and dietary fiber are frequently considered as functional foods since their products can be designed to improve consumer health (Lobo et al., 2010; Poutanen, 2012).

According to Ma et al. (2014), the expression of genes involved in flavonoid biosynthesis and accumulation of polyphenolic compounds in wheat could be closely related to drought. In addition, the response mechanism for flavonoid biosynthesis may be different between wheat cultivars. It has been reported that different genotypes of wheat subjected to different levels of soil $\mathrm{N}$ and water stress, present changes in the composition and protein quality of the grain (Saint Pierre et al., 2008). Several epidemiological studies have reported that polyphenolic compounds present in foods made from whole wheat flour contribute to maintain consumer health, mainly due to its antioxidant, anticancer and antimicrobial activity (Lv et al., 2012; Andersson et al., 2014). Furthermore, it has been reported that anthocyanins and phenolic acids are contained in greater proportion in wheat seeds that present dark coloration (Liu et al., 2010; Ivanisová et al., 2014). Several studies have investigated the antioxidant properties, nutritional and phytochemical compositions of wheat grain or its milling fractions (Lv et al., 2012; Ivanisová et al., 2014). These previous studies also indicated that different wheat genotypes, growing environment, interaction between genotype and environment, and cultivation system may significantly alter the health properties of wheat grain (Dinelli et al., 2013; Pandino et al., 2020).

Certainly, there are currently several studies and researches that use models and methodologies to simulate the effects that climate change can have on agricultural crops and within this context, how drought and increase of extreme temperatures negatively affect productivity and yields of the crops (Hernandez et al., 2015; García et al., 2016; Mäkinen et al., 2018). However, in Chile there is little information on studies at field level that focus in the effect that drought has during grain filling stage in wheat and how it can affect the total polyphenol content and grain yield. The aim of the present research was to study the influence of different levels of water deficit on total polyphenol content and grain yield in spring wheat cultivars, during grain filling stage.

\section{MATERIALS AND METHODS}

\section{Description of experimental sites}

Experimental plots were established under field conditions during 2016-2017 growing season at two sites located in Ñuble Region, Chile: Site 1 (36³9'28.7” S, 7149'15.9” W, 292 m a.s.1.), La Escoba Farm's, Coihueco, and Site $2\left(36^{\circ} 35^{\prime} 58.5^{\prime \prime}\right.$ S, $72^{\circ} 04^{\prime} 47.4^{\prime}$ W, 135 m a.s.1.) corresponds to "El Nogal" Experimental Station, in the University of Concepción, Campus Chillán. The first site corresponds to an Andisol, with a clay loam texture (Table 1), classified as medial, amorphic, mesic, Typic, Haploxerands, with an undulating topography and complex slopes and good drainage. The second site corresponds to an Andisol, with loam texture (Table 1), classified as medial, amorphic, thermic, Humic Haploxerands, the topography is flat with simple slopes in the range of $0 \%$ to $1 \%$ and good drainage (Stolpe, 2011). Both experimental sites have deep soils (Stolpe, 2011). The climate is classified as temperate Mediterranean, with an average annual rainfall of 1000 to $1200 \mathrm{~mm}$, with concentrated rainfall between May and August, and a dry season of 4 to 5 months, with an average temperature of $13.1^{\circ} \mathrm{C}$, a maximum temperature of 28 to $30^{\circ} \mathrm{C}$ in January, and a minimum temperature of 3 to $5^{\circ} \mathrm{C}$ in July (del Pozo and del Canto, 1999).

\section{Experimental design and management crop}

In both locations the experiments were established under a randomized complete block design (RCBD), with a split-plot arrangement, with 12 treatments and 4 replicates, where the main plot was the irrigation level (irrigations events during grain filling stage): three irrigations (well-watered), one irrigation (moderate-deficit) and without irrigation (severe-deficit), and the sub-plot corresponded to different cultivars of spring wheat. The experimental unit corresponded to a plot of 10 $\mathrm{m}^{2}$, consisting of 10 rows separated to a distance of $0.2 \mathrm{~m} \times 5 \mathrm{~m}$ long. Cultivars used were Pandora-INIA, Pantera- 
Table 1. Chemical and physical soil properties of experimental sites during 2016-2017 growing season $(0-30 \mathrm{~cm})$.

\begin{tabular}{|c|c|c|}
\hline \multirow[b]{2}{*}{ Chemical parameters } & \multicolumn{2}{|c|}{ Soil } \\
\hline & Site 1 (Coihueco) & Site 2 (Chillán) \\
\hline $\mathrm{pH}$ & 6.44 & 6.89 \\
\hline Organic matter, $\%$ & 12.07 & 6.17 \\
\hline $\mathrm{N}-\mathrm{NO}_{3}, \mathrm{mg} \mathrm{kg}^{-1}$ & 3.80 & 3.10 \\
\hline $\mathrm{N}-\mathrm{NH}_{4}, \mathrm{mg} \mathrm{kg}^{-1}$ & 5.90 & 5.50 \\
\hline Inorganic $\mathrm{N}, \mathrm{mg} \mathrm{kg}^{-1}$ & 9.70 & 8.60 \\
\hline P-Olsen, $\mathrm{mg} \mathrm{kg}^{-1}$ & 10.70 & 36.00 \\
\hline Exchangeable K, $\mathrm{cmol}_{(+)} \mathrm{kg}^{-1}$ & 0.66 & 1.61 \\
\hline Exchangeable $\mathrm{Ca}, \mathrm{cmol}_{(+)} \mathrm{kg}^{-1}$ & 8.60 & 7.91 \\
\hline Exchangeable $\mathrm{Mg}, \mathrm{cmol}_{(+)} \mathrm{kg}^{-1}$ & 1.28 & 1.07 \\
\hline Exchangeable $\mathrm{Na}, \mathrm{cmol}_{(+)} \mathrm{kg}^{-1}$ & 0.16 & 0.05 \\
\hline Exchangeable $\mathrm{Al}, \mathrm{cmol}_{(+)} \mathrm{kg}^{-1}$ & 0.05 & 0.40 \\
\hline Effective cation exchange capacity (ECEC), $\mathrm{cmol}_{(+)} \mathrm{kg}^{-1}$ & 10.75 & 11.03 \\
\hline Available $\mathrm{K}, \mathrm{mg} \mathrm{kg}^{-1}$ & 256.60 & 626.00 \\
\hline Available $\mathrm{S}, \mathrm{mg} \mathrm{kg}^{-1}$ & 11.10 & 6.20 \\
\hline Available $\mathrm{Fe}, \mathrm{mg} \mathrm{kg}^{-1}$ & 42.00 & 26.60 \\
\hline Available $\mathrm{Mn}, \mathrm{mg} \mathrm{kg}^{-1}$ & 9.60 & 0.60 \\
\hline Available $\mathrm{Zn}, \mathrm{mg} \mathrm{kg}^{-1}$ & 0.70 & 0.70 \\
\hline Available $\mathrm{Cu}, \mathrm{mg} \mathrm{kg}^{-1}$ & 2.40 & 1.50 \\
\hline Available B, $\mathrm{mg} \mathrm{kg}^{-1}$ & 0.20 & 0.30 \\
\hline \multicolumn{3}{|l|}{ Physical parameters } \\
\hline Sand, $\%$ & 28.10 & 42.50 \\
\hline Silt, $\%$ & 43.90 & 31.00 \\
\hline Clay, $\%$ & 28.10 & 26.50 \\
\hline Soil texture ${ }^{1}$ & Clayey loam & Loamy \\
\hline Bulk density, $\mathrm{g} \mathrm{cm}^{-3}$ & 1.13 & 1.21 \\
\hline Field capacity (FC), $\%$ & 51.11 & 26.46 \\
\hline Permanent wilting point (PWP), \% & 28.11 & 14.54 \\
\hline Available water (AW), \% & 23.00 & 11.92 \\
\hline
\end{tabular}

${ }^{1}$ According to the USDA system.

INIA CL, Lasana and Suri. Which were sown at the end of August 2016, with seeding rate of $220 \mathrm{~kg} \mathrm{ha}^{-1}$ in each cultivar. Before sowing, seeds were disinfected with a fungicide fluquinconazole $\left(167.2 \mathrm{~g}\right.$ ai $100 \mathrm{~kg}^{-1}$ seed $)+$ prochloraz (31.2 g ai $100 \mathrm{~kg}^{-1}$ seed) (Galmano Plus FS, Bayer S.A, Chile). Two months prior to the establishment of trials, a chemical fallow was applied with a total herbicide paraquat (paraquat dichloride, $166 \mathrm{~g}_{\text {ai }} \mathrm{L}^{-1}$ ) + diquat (diquat dibromide, $149 \mathrm{~g}$ ai L $^{-1}$ ) (Farmon SL, Syngenta, Chile) at both experimental sites. The sowing was done in a traditional way prior to soil preparation, with application of glyphosate (glyphosate-isopropylammonium/N-phosphonomethyl-glycine) as a preemergence herbicide, applied at the rate of $0.96 \mathrm{ai} \mathrm{L} \mathrm{ha}^{-1}$ (Rango $480 \mathrm{SL}$, ANASAC, Chile) to control broadleaf and grass weeds. A post emergence herbicide was sprayed at tillering stage (Z2.3) (Zadoks et al., 1974), by applying iodosulfuron-methyl-sodium 0.157 ai kg ha-1 (Ovassion 5.26 WP, ANASAC, Chile), selective systemic herbicide to control broadleaf and grass weeds in wheat, together with an adherent-humectant (Winspray Miscible EC, ANASAC, Chile).

Fertilization was calculated according to soil chemical analysis, applying at sowing in Site $2180 \mathrm{~kg} \mathrm{ha}^{-1}$ diammonium phosphate, $160 \mathrm{~kg} \mathrm{ha}^{-1}$ potassium su lfate, $10 \mathrm{~kg} \mathrm{ha}^{-1}$ boronatrocalcite, and $3 \mathrm{~kg} \mathrm{ha}^{-1} \mathrm{Zn}$ sulfate. In Site 1 fertilization was at sowing with $326 \mathrm{~kg} \mathrm{ha}^{-1}$ diammonium phosphate, $160 \mathrm{~kg} \mathrm{ha}^{-1}$ potassium sulfate, $10 \mathrm{~kg} \mathrm{ha}^{-1}$ boronatrocalcite, and $3 \mathrm{~kg} \mathrm{ha}{ }^{-1} \mathrm{Zn}$ sulfate. The $\mathrm{N}$ fertilization was partitioned, with 200 units as urea: 60 units $\left(130 \mathrm{~kg} \mathrm{ha}^{-1}\right)$ at sowing, $60 \mathrm{units}\left(130 \mathrm{~kg} \mathrm{ha}^{-1}\right)$ at the start of tillering (Z 2.1 Zadoks scale) and 80 units (174 kg ha-1) at the end of the tillering (Z 2.4 Zadoks scale) (Zadoks et al., 1974). Application of foliar fungicides and insecticides was not necessary.

\section{Irrigation management}

Plots were uniformly irrigated to replace $100 \%$ crop evapotranspiration $\left(\mathrm{ET}_{0}\right)$ until $1 \mathrm{wk}$ after anthesis, according to the needs of the crop. Later, irrigation was applied through a siphon irrigation system, with a flow rate average of $2 \mathrm{~L} \mathrm{~s}^{-1}$ in each plot. Irrigation frequency fluctuated between 6 and $7 \mathrm{~d}$ and the watering time between 2 and $2.5 \mathrm{~h}$. Irrigation was scheduled using climatic data and evapotranspiration $\left(\mathrm{ET}_{0}\right)$ measurements from automatic weather stations, according 
to data provided by the Agrometeorological Station of University of Concepción in Chillán and the Agrometeorological Station of Coihueco. Three irrigation levels were applied during the grain filling stage, reaching full irrigation (three irrigations), moderate deficit (one irrigation) and severe deficit (without irrigation).

According to wheat general growth stages, in the center-south of Chile, irrigation treatments were applied $10 \mathrm{~d}$ after anthesis (DAA). Anthesis was estimated as 50\% of the ears of the plot had visible anthers (Z 6.5) (Zadoks et al., 1974). Temperatures, cumulative rainfall, relativity humidity and solar radiation records were obtained from automatic weather stations located near the field trial sites (Table 2).

\section{Sampling and yield measurements}

The five-central rows $\left(2 \mathrm{~m}^{2}\right)$ of each plot were manually cut with a sickle and threshed with a stationary thresher (Model LPT, Almaco, Nevada, Iowa, USA) to express grain yield as $\mathrm{Mg} \mathrm{ha}^{-1}$. Yield components, such as spikes $\mathrm{m}^{-2}$, grains per spike, and 1000 seed weight (TSW), were determined from plants harvested from a $1 \mathrm{~m}$ (excluding border plants) randomly sampled from each plot. Plots were harvested during the first half of January 2017, in both locations, when at least 50\% all plants had reached the stage of harvest maturity (Mellado, 2007).

Wheat grain samples were cleaned by an air seed cleaner (Model ABSC, Almaco) and stored on a shelf at room temperature until used. The thousand-seed weight (TSW) was calculated by precision seed counter (ELE International, Leighton Buzzard, UK) and an analytical precision balance (Model 1000C-3000D, Precisa, Zurich, Switzerland) for each plot-sample. To determine the moisture content of wheat (data not shown), a moisture meter was used (DMC 750, Burrows, Chicago, Illinois, USA). Subsequently, grain yield was corrected to a moisture content of $14 \%$, with a $Y=\left(Y_{l}\right.$ $(1-a)) /(1-b)$ equation according to Mellado (2007), being $Y$ yield at $14 \%$ moisture, $Y_{I}$ yield, $a$ moisture of harvested grain and $b$ moisture to which you want to express grain yield.

\section{Extraction and determination of total polyphenol content}

Samples of $100 \mathrm{~g}$ wheat seeds were ground on centrifugal experimental mill (Cyclotec 1093 Sample Mill, FossTecator, Hillerød, Denmark) using a 35 mesh screen. A sample of $1 \mathrm{~g}$ whole wheat flour for each treatment was extracted with $5 \mathrm{~mL}$ water:methanol:formic acid (24:25:1) solution and placed in ultrasonic cleaner (M5800H, Branson Ultrasonics, Danbury, Connecticut, USA) for $60 \mathrm{~min}$. Allow to rest for $24 \mathrm{~h}$ to re-sonicate for $1 \mathrm{~h}$, then centrifuged (L535R, Xiangyi Centrifuge Instrument, Changsha, China) for $15 \mathrm{~min}$ at $3500 \mathrm{rpm}$. The liquid phase of the extracts was filtered through Whatman $\mathrm{Nr} 2$ paper and stored at $4{ }^{\circ} \mathrm{C}$ until used. Total polyphenol content (TPC) of each extract was measured using the colorimetric Folin-Ciocalteu method as described by Lv et al. (2012). Briefly, each fraction $(0.5 \mathrm{~mL})$ was mixed with $1 \mathrm{~mL}$ FolinCiocalteu reagent and $0.8 \mathrm{~mL}$ saturated sodium carbonate $\left(\mathrm{Na}_{2} \mathrm{CO}_{3}\right)$ solution. The mixture was allowed to stand for $30 \mathrm{~min}$ at room temperature in dark. The absorbance was measured at $760 \mathrm{~nm}$ in a spectrophotometer (Orion AquaMate 7000, Thermo Scientific, Waltham, Massachusetts, USA). Total polyphenol content was expressed as mg gallic acid equivalent (GAE) $100 \mathrm{~g}^{-1}$ sample. All measurements were performed in triplicate. All chemicals, reagents, and standards were ACS or HPLC grade. Gallic acid and Folin-Ciocalteu reagent were purchased from Sigma-Aldrich (St. Louis, Missouri, USA).

Table 2. Mean monthly maximum $\left(\mathrm{T}^{\circ}\right.$ max.) and minimum $\left(\mathrm{T}^{\circ} \mathrm{min}.\right)$ air temperature, rainfall, relative humidity $(\mathrm{RH})$, solar radiation and evapotranspiration $\left(\mathbf{E T}_{0}\right)$ of field experiments in both locations in 2016-2017 growing season.

\begin{tabular}{|c|c|c|c|c|c|c|c|c|c|}
\hline Location & Month & $\mathrm{T}^{\circ} \max$. & $\mathrm{T}^{\circ} \min$. & $\mathrm{T}^{\circ}$ media & RH & Rainfall & $\begin{array}{c}\text { Solar } \\
\text { radiation }\end{array}$ & $\mathrm{ET}_{0}$ & $\mathrm{ET}_{0}$ \\
\hline & & & $-{ }^{\circ} \mathrm{C}$ & - & $\%$ & $\mathrm{~mm} \mathrm{mo}^{-1}$ & $\mathrm{MJ} \mathrm{m}^{-2} \mathrm{~d}^{-1}$ & $\mathrm{~mm} \mathrm{mo}^{-1}$ & $\mathrm{~mm} \mathrm{~d}^{-1}$ \\
\hline \multirow[t]{6}{*}{ Site 1} & August & 15.7 & 2.8 & 8.7 & 89.2 & 59.2 & 9.2 & 43.9 & 1.4 \\
\hline & September & 20.8 & 4.2 & 12.0 & 76.6 & 24.5 & 15.2 & 81.5 & 2.7 \\
\hline & October & 21.4 & 5.3 & 12.7 & 82.1 & 74.4 & 18.0 & 96.1 & 3.1 \\
\hline & November & 26.1 & 6.2 & 16.0 & 76.6 & 29.4 & 24.9 & 140.3 & 4.7 \\
\hline & December & 27.6 & 7.8 & 17.3 & 74.9 & 29.3 & 25.7 & 153.0 & 4.9 \\
\hline & January & 31.7 & 8.2 & 20.1 & 65.4 & 9.8 & 28.0 & 193.1 & 6.2 \\
\hline \multirow[t]{6}{*}{ Site 2} & August & 14.7 & 4.5 & 9.2 & 68.8 & 53.0 & 9.2 & 0.4 & 0.0 \\
\hline & September & 20.2 & 5.8 & 12.4 & 59.4 & 22.2 & 15.3 & 17.4 & 0.6 \\
\hline & October & 19.9 & 6.7 & 13.1 & 60.5 & 65.1 & 18.7 & 103.8 & 3.3 \\
\hline & November & 25.6 & 9.6 & 17.3 & 51.9 & 13.6 & 25.5 & 165.8 & 5.5 \\
\hline & December & 26.0 & 10.4 & 17.8 & 51.8 & 25.7 & 26.8 & 208.9 & 6.7 \\
\hline & January & 30.2 & 12.8 & 21.5 & 41.6 & 3.5 & 28.5 & 0.0 & 0.0 \\
\hline
\end{tabular}




\section{Statistical analysis}

The statistical analysis was conducted using standard procedures for a randomized complete block design with a splitplot arrangement. To determine differences between treatments, after a homoscedasticity and normality tests, results of each trial were analyzed by ANOVA with SAS software (SAS Institute, Cary, North Carolina, USA) and least significant difference (LSD) test $(\mathrm{P} \leq 0.05)$. The conversion of percentage data was made by the relationship $\sqrt{ }(\mathrm{x}+0.5)$ to adjust them to normal distribution.

\section{RESULTS}

\section{Effect of water deficit on yield components}

There was not interaction between irrigation level and cultivar; however, there were differences between irrigation levels and cultivars (Table 3). Respect to Site 1 (Coihueco), there were significant differences in the means of number of spikes $\mathrm{m}^{-2}$ observed at different levels of irrigation, where the higher number of spikes being observed at well-watered and moderate water deficit treatments, these being significantly similar $(\mathrm{P}<0.05)$. The plots subjected to severe water deficit registered the lowest number of spikes $\mathrm{m}^{-2}$, presenting differences with respect to the two previously mentioned regimes $(\mathrm{P}<0.05)$. In this same variable, significant differences were also observed in cultivars, where 'Suri' presented on average up to 50 spikes $\mathrm{m}^{-2}$ more than the rest of studied cultivars, being different from all the rest of them $(\mathrm{P}<0.05)$. 'Lasana' is also significantly different from the other cultivars, obtaining about 485 spikes $\mathrm{m}^{-2}$, while 'Pantera-INIA CL' and 'Pandora-INIA' behaved in the same way, registering numbers of homogeneous spikes $\mathrm{m}^{-2}$ that did not displace in more than 10 spikes $\mathrm{m}^{-2}$. In grains per spike, a similar response to the previous variable was observed, where differences were obtained in the means at different irrigation levels $(\mathrm{P}<0.05)$. In this sense, a higher number of grains per spike were registered in plots well-watered and with moderate deficit irrigation, being similar among them and greater than plots without irrigation. In the means obtained by cultivars is observed that 'Suri' presented greater number of grains per spike than the rest of cultivars, which reached homogeneous values among themselves. In TSW there were no differences between the means at different levels of irrigation, however, the cultivars did show significant differences, where 'Lasana' and 'Pantera-INIA CL' behaved the same $(\mathrm{P}<0.05)$, showing the highest weights of 1000 grains of the four cultivars studied, followed by 'Pandora-INIA'. Contrary to the results previously shown, 'Suri' presented the lowest weight of 1000 grains of the cultivars, despite showing greater number of spikes $\mathrm{m}^{-2}$ and grains per spike.

In Site 2 (Chillán), the means at different levels of irrigation show differences only in the number of spikes $\mathrm{m}^{-2}$, where the three levels of water availability showed differences among themselves $(\mathrm{P}<0.05)$ (Table 3), observing a higher number of spikes in plots well-watered, and conversely, a smaller number in plots with severe deficit. With respect to this variable, it is observed that 'Lasana' was significantly different from all other cultivars, reaching the maximum of 576 spikes $\mathrm{m}^{-2}$, followed by 'Pantera-INIA CL' and 'Pandora-INIA', that behaved significantly the same averaging 457

Table 3. Spikes per square meter, grains per spike and thousand seed weight (TSW) of four spring wheat cultivars in both evaluated locations.

\begin{tabular}{|c|c|c|c|c|c|c|c|c|c|c|c|c|c|c|c|c|}
\hline \multirow[b]{2}{*}{ Location } & \multirow[b]{2}{*}{ Irrigation } & \multicolumn{5}{|c|}{ Spikes $m^{-2}(n r)$} & \multicolumn{5}{|c|}{ Grains per spike (nr) } & \multicolumn{5}{|c|}{ TSW (g) } \\
\hline & & Lasana & $\begin{array}{l}\text { Pantera } \\
\text { INIA CL }\end{array}$ & Suri & $\begin{array}{c}\text { Pandora } \\
\text { INIA }\end{array}$ & Mean $^{1}$ & Lasana & $\begin{array}{l}\text { Pantera } \\
\text { INIA CL }\end{array}$ & Suri & $\begin{array}{c}\text { Pandora } \\
\text { INIA }\end{array}$ & Mean $^{1}$ & Lasana & $\begin{array}{l}\text { Pantera } \\
\text { INIA CL }\end{array}$ & Suri & $\begin{array}{c}\text { Pandora } \\
\text { INIA }\end{array}$ & Mean $^{1}$ \\
\hline \multirow[t]{5}{*}{ Site 1} & Well-watered & 524 & 481 & 526 & 455 & 497A & 41 & 38 & 45 & 42 & $41 \mathrm{~A}$ & 46.5 & 46.8 & 37.4 & 46.0 & $44.2 \mathrm{~A}$ \\
\hline & Moderate deficit & 456 & 465 & 534 & 458 & $478 \mathrm{~A}$ & 41 & 38 & 45 & 39 & $40 \mathrm{~A}$ & 46.4 & 46.4 & 37.6 & 45.3 & $43.9 \mathrm{~A}$ \\
\hline & Severe deficit & 473 & 420 & 475 & 421 & 447B & 31 & 38 & 40 & 37 & 37B & 46.6 & 47.4 & 38.2 & 44.9 & $44.2 \mathrm{~A}$ \\
\hline & Mean $^{1}$ & $484 b$ & $455 \mathrm{c}$ & $512 \mathrm{a}$ & $445 \mathrm{c}$ & & $38 b$ & $38 b$ & $43 a$ & $39 b$ & & $46.5 \mathrm{a}$ & $46.9 \mathrm{a}$ & $37.7 \mathrm{c}$ & $45.4 \mathrm{~b}$ & \\
\hline & $\mathrm{CV}, \%$ & \multicolumn{4}{|c|}{6.48} & & \multicolumn{5}{|c|}{11.23} & \multicolumn{4}{|c|}{2.56} & \\
\hline \multirow[t]{5}{*}{ Site 2} & Well-watered & 615 & 469 & 411 & 555 & $513 \mathrm{~A}$ & 25 & 33 & 42 & 27 & $31 \mathrm{~A}$ & 40.9 & 41.8 & 36.9 & 44.3 & $41.0 \mathrm{~A}$ \\
\hline & Moderate deficit & 590 & 448 & 379 & 446 & $466 \mathrm{~B}$ & 27 & 33 & 32 & 31 & $31 \mathrm{~A}$ & 41.1 & 39.2 & 36.9 & 42.1 & $39.8 \mathrm{~A}$ \\
\hline & Severe deficit & 523 & 436 & 375 & 389 & $431 \mathrm{C}$ & 26 & 23 & 29 & 28 & $26 \mathrm{~A}$ & 39.4 & 41.9 & 36.1 & 40.3 & $39.4 \mathrm{~A}$ \\
\hline & Mean $^{1}$ & $576 a$ & $451 b$ & $388 \mathrm{c}$ & $463 b$ & & $26 b$ & $30 \mathrm{~b}$ & $34 \mathrm{a}$ & $29 b$ & & $40.4 b$ & $41.0 \mathrm{ab}$ & $36.6 \mathrm{c}$ & $42.2 \mathrm{a}$ & \\
\hline & $\mathrm{CV}, \%$ & \multicolumn{5}{|c|}{5.84} & \multicolumn{5}{|c|}{17.02} & \multicolumn{3}{|c|}{4.91} & & \\
\hline
\end{tabular}

${ }^{1}$ Means with different uppercase letters in columns indicate differences among levels of water deficit $(\mathrm{P}<0.05)$ according to LSD test, while means with different lowercase letters in rows indicate differences among cultivars of wheat $(\mathrm{P}<0.05)$ according to LSD test.

CV: Coefficient of variation. 
spikes $\mathrm{m}^{-2}$. 'Suri' reached the lowest number of spikes, being significantly different from other cultivars. In the number of grains per spike, an inverse behavior was observed to data previously described, where the means of the different cultivars studied show that 'Suri' reached the highest number of grains per spike, being different from the rest of cultivars $(\mathrm{P}<0.05)$, reaching average of 6 grains more per spike than the rest. In TSW, 'Pantera-INIA CL' and 'Pandora-INIA' reached the highest values, which fluctuated between 41 and $42 \mathrm{~g}$, being significantly equal to each other. 'Suri' behaved differently from the rest of the three cultivars studied, reaching an average of $4.6 \mathrm{~g}$ less than the rest of cultivars.

In Site 1 interaction was obtained between water deficit level and cultivar (Table 4). 'Pantera-INIA' and 'Lasana' showed decreased yield with severe water deficit. It should be noted that 'Pantera-INIA CL' and 'Lasana' did not show significant differences between well-watered and moderate water deficit treatments, while in 'Suri' and 'PandoraINIA' nonsignificant differences were obtained between the three irrigation levels evaluated. In 'Pantera-INIA CL' and 'Lasana', only plots with no water replenishment decreased significantly the yield compared to moderate water deficit and well-watered treatment; while in 'Pandora-INIA' and 'Suri' there was not effect of water deficit on performance. When comparing the yield of the four cultivars in conditions without water deficit (well-watered), 'Pantera-INIA CL' and 'Suri' showed the highest yield, reaching 10.5 and $9.5 \mathrm{Mg} \mathrm{ha}^{-1}$, respectively. In this same water deficit level, the less productive cultivars were Lasana and Pandora-INIA, with 9.1 and $8.8 \mathrm{Mg} \mathrm{ha}^{-1}$, respectively, being significantly lower compared to the moderate water deficit level in the two cultivars mentioned above. On the other hand, with a moderate water deficit level, the four cultivars had equal yields, ranging from 9.4 to $9.9 \mathrm{Mg} \mathrm{ha}^{-1}$. Finally, for a severe water deficit level, 'Lasana' was the only cultivar that significantly decreased yield compared to the other three cultivars. In Site 2, there was nonsignificant interaction between water deficit level and cultivar, or among the three water deficit levels applied either. However, there were significant differences between cultivars, being 'Lasana' and 'Pantera-INIA CL' significantly equal ( $\mathrm{P}>0.05)$, with an average yield of 7.1 and $6.8 \mathrm{Mg} \mathrm{ha}^{-1}$, respectively, and both greater than 'Suri' and 'Pandora-INIA', which had the lowest yield reaching 6.4 and $6.1 \mathrm{Mg} \mathrm{ha}^{-1}$, respectively (Table 4).

\section{Effect of water deficit on total polyphenol content}

There was not interaction between irrigation level and cultivar ( $\mathrm{P}>0.05)$; however, this variable responded different to cultivars $(\mathrm{P}<0.05)$ (Table 5). Respect to the means of the different irrigation levels, nonsignificant differences were observed between treatments in any of the mentioned cultivars in both sites, with similar results $(\mathrm{P}>0.05)$ on polyphenols contents (mg GAE $100 \mathrm{~g} \mathrm{~g}^{-1}$ ) in spring wheat cultivars based on the water availability to which they were exposed (Table 5). In relation to cultivars, in Site 1 it was observed that in total polyphenol content in whole wheat flour samples, 'PandoraINIA' had the highest value with $158.3 \mathrm{mg}$ GAE $100 \mathrm{~g}^{-1}$, but equal than content in 'Lasana' (141.0 mg GAE $\left.100 \mathrm{~g} \mathrm{~g}^{-1}\right)$. 'Pantera-INIA CL' and 'Suri' obtained homogeneous levels that did not exceed $125.6 \mathrm{mg}$ GAE $100 \mathrm{~g}^{-1}$, being significantly equal to each other. In Site 2, 'Lasana' and 'Pandora-INIA' presented the highest polyphenol contents, which fluctuated between 96 and $101 \mathrm{mg}$ GAE $100 \mathrm{~g}^{-1}$, being significantly the same. 'Pantera-INIA CL' and 'Suri' showed lower total polyphenol contents than those previously mentioned, reaching levels that did not exceed $77.1 \mathrm{mg}^{\mathrm{GAE}} 100 \mathrm{~g}^{-1}$ and significantly equal.

Table 4. Grain yield of four spring wheat cultivars in both evaluated locations.

\begin{tabular}{|c|c|c|c|c|c|c|}
\hline \multirow[b]{2}{*}{ Location } & \multirow[b]{2}{*}{ Irrigation } & \multicolumn{4}{|c|}{ Grain yield $\left(\mathrm{Mg} \mathrm{ha}^{-1}\right)$} & \multirow[b]{2}{*}{ Mean $^{1}$} \\
\hline & & Lasana & Pantera-INIA CL & Suri & Pandora-INIA & \\
\hline \multirow[t]{4}{*}{ Site 1} & Well-watered & $9.1 \mathrm{Ab}$ & $10.5 \mathrm{Aa}$ & $9.5 \mathrm{Aa}$ & $8.8 \mathrm{Ab}$ & \\
\hline & Moderate deficit & $9.8 \mathrm{Aa}$ & 9.9Aa & $9.5 \mathrm{Aa}$ & $9.4 \mathrm{Aa}$ & \\
\hline & Severe deficit & $8.5 \mathrm{Bb}$ & $9.3 \mathrm{Ba}$ & $9.0 \mathrm{Aa}$ & $9.3 \mathrm{Aa}$ & \\
\hline & $\mathrm{CV}, \%$ & \multicolumn{4}{|c|}{5.0} & \\
\hline \multirow[t]{5}{*}{ Site 2} & Well-watered & 7.1 & 7.0 & 6.5 & 6.0 & $6.7 \mathrm{~A}$ \\
\hline & Moderate deficit & 7.4 & 6.9 & 6.3 & 6.6 & $6.8 \mathrm{~A}$ \\
\hline & Severe deficit & 6.7 & 6.5 & 6.3 & 5.8 & $6.3 \mathrm{~A}$ \\
\hline & Mean $^{1}$ & $7.1 \mathrm{a}$ & $6.8 \mathrm{a}$ & $6.4 \mathrm{~b}$ & $6.1 \mathrm{~b}$ & \\
\hline & $\mathrm{CV}, \%$ & \multicolumn{4}{|c|}{7.1} & \\
\hline
\end{tabular}

${ }^{1}$ Means with different lowercase letters indicate differences among cultivars $(\mathrm{P}<0.05)$ according to LSD test, while different uppercase letters indicate differences among water deficit level $(\mathrm{P}<0.05)$ according to LSD test. $\mathrm{CV}$ : Coefficient of variation. 
Table 5. Total polyphenol content (TPC) of four spring wheat cultivars in both evaluated locations.

\begin{tabular}{|c|c|c|c|c|c|c|}
\hline \multirow[b]{2}{*}{ Location } & \multirow[b]{2}{*}{ Irrigation } & \multicolumn{4}{|c|}{ TPC (mg GAE $\left.100 \mathrm{~g}^{-1}\right)$} & \multirow[b]{2}{*}{ Mean $^{1}$} \\
\hline & & Lasana & Pantera-INIA CL & Suri & Pandora-INIA & \\
\hline \multirow[t]{5}{*}{ Site 1} & Well-watered & 155.0 & 123.5 & 122.7 & 141.1 & $135.6 \mathrm{~A}$ \\
\hline & Moderate deficit & 154.3 & 128.7 & 143.8 & 178.2 & $151.3 \mathrm{~A}$ \\
\hline & Severe deficit & 113.5 & 119.9 & 110.2 & 155.5 & $124.8 \mathrm{~A}$ \\
\hline & Mean $^{1}$ & $141.0 \mathrm{ab}$ & $124.0 \mathrm{~b}$ & $125.6 \mathrm{~b}$ & $158.3 \mathrm{a}$ & \\
\hline & $\mathrm{CV}, \%$ & \multicolumn{4}{|c|}{5.74} & \\
\hline \multirow[t]{5}{*}{ Site 2} & Well-watered & 112.5 & 80.7 & 73.9 & 80.9 & $87.0 \mathrm{~A}$ \\
\hline & Moderate deficit & 88.8 & 82.5 & 77.8 & 118.6 & $91.9 \mathrm{~A}$ \\
\hline & Severe deficit & 103.1 & 68.3 & 66.1 & 89.7 & $81.8 \mathrm{~A}$ \\
\hline & Mean $^{1}$ & $101.5 \mathrm{a}$ & $77.1 \mathrm{bc}$ & $72.6 \mathrm{c}$ & $96.4 \mathrm{ab}$ & \\
\hline & $\mathrm{CV}, \%$ & \multicolumn{4}{|c|}{6.19} & \\
\hline
\end{tabular}

${ }^{1}$ Means with different uppercase letters in columns indicate differences among levels of water deficit $(\mathrm{P}<0.05)$ according to LSD test, while means with different lowercase letters in rows indicate significant differences among cultivars of wheat $(\mathrm{P}<0.05)$ according to LSD test.

CV: Coefficient of variation.

\section{DISCUSSION}

Drought is one of most important abiotic stress and is one of the main constraints for crop production and food security around the world. The situation has worsened due to drastic and rapid changes in the global climate. A wide range of responses of plants to these stresses could be generalized in morphological, physiological and biochemical responses (Fahad et al., 2017). It is very important to understand these constrains for better management. During the 2016-2017 growing season, in both locations, there was nonsignificant interaction between water deficit level and cultivar for yield components, such as number of spikes $\mathrm{m}^{-2}$, number of grains per spike and TSW (Zhang et al., 2019). However, there were significant differences between irrigation levels and cultivars, for the yield components mentioned above. Rajala et al. (2009) reported a reduction in the number of spikes $\mathrm{m}^{-2}$ in a spring wheat cultivar, product of a terminal drought, indicating that grain abortion occurs in wheat after pollination.

Notwithstanding the foregoing, it should be noted that there was no rainfall during the period of application of water deficit in both locations; however, a precipitation of 19.0 and $19.9 \mathrm{~mm}$ was recorded on 25 December 2016, in Coihueco and Chillán, respectively. The rains recorded has no longer influence the yield components, since the wheat was in the stage of grain drying, specifically semi-hard grain (Mellado, 2007). It is important to highlight that the late rains that occurred in December 2016, could have affected the yield to wheat harvest, since these rains led to the development of late tillers, which could have interfered with the translocation of photoassimilates to the grain, causing detriment of yield (Rajala et al., 2011). Respect to this, there was a greater number of late tillers (data not shown) in well-watered plots, where $100 \%$ water availability was maintained. Similarly, Rajala et al. (2011) reported that under field conditions an adequate water availability during grain filling increases late tillering, although this late tillering does not promote good grain yield due to quantity and quality of late tillers is often lower, and also delay harvesting due to uneven grain ripening. This could explain that 'Lasana' and 'Pandora-INIA' had a lower grain yield in the locality of Coihueco, when compared with the moderate water deficit level, since being subjected to more frequent irrigation, a greater water availability favored the emission of late tillers and a greater development of weeds, thus achieving lower yields due to the severe competition of weeds with wheat for growth resources (Rajala et al., 2011; Hussain et al., 2017).

When comparing temperatures at study sites, higher average temperatures were recorded in the Site 2 (Chillán) than in Site 1 (Coihueco) during November 2016, being $17.3 \mathrm{vs} .16 .0^{\circ} \mathrm{C}$, respectively. This difference in temperature could have affected the final grain yield obtained in Site 2, since during November the wheat in Chillán was in sensitive stages such as anthesis and fecundation (Mellado, 2007; Lizana and Calderini, 2013). An accelerated development under high temperatures led to a shorter effective grain filling period, reducing final grain weight (García et al., 2016). In this context, the increase in the minimum daily temperature has a greater impact on wheat production, since grain yield is more strongly correlated with the increase in minimum temperatures than maximum temperatures (Farooq et al., 2011). Besides, the drought induced at the pre anthesis stage, could shorten the time to anthesis while that applied after anthesis, could reduce the period of grain filling in cereals (Daryanto et al., 2016). 
Respect to grain yield, despite the fact that in Site 1 there was significant interaction between water availability and cultivar, where 'Pantera-INIA CL' with well-watered treatment reached the highest yield $\left(10.5 \mathrm{Mg} \mathrm{ha}^{-1}\right)$ although it did not differ from 'Suri' at the same level of irrigation. On the other side, 'Lasana' with a severe water deficit obtained the lowest grain yield $\left(8.5 \mathrm{Mg} \mathrm{ha}^{-1}\right)$, but not differing from the well-watered treatment. Under the conditions of this study, it is important to note that was not observed a clear trend that lower water availability significantly affected grain yield of all wheat cultivars. However, in another study where the water stress was applied from the beginning of crop cycle in contrasting environments, significant differences in yield were observed for a set of 384 wheat genotypes grown under water stress, mild water stress and full irrigation in a Mediterranean environment (del Pozo et al., 2016).

Stem water-soluble carbohydrate (SWSC) are accumulated prior to anthesis and then they are remobilized to the grain during grain-filling period. In wheat, water-soluble carbohydrates (WSC) accumulated until anthesis exhibit higher contents under conditions of water stress than under well-watered conditions (del Pozo et al., 2016). Therefore, the decrease in WSC from anthesis to maturity is greater in conditions of water deficit than under normal irrigation conditions (Zhang et al., 2019), which suggests that there is a greater mobilization of reserves during the filling of grain under these conditions (del Pozo et al., 2016). Under water limiting conditions, where canopy photosynthesis is inhibited, the contribution of stem carbohydrates to grain growth could be very significant (Lopes and Reynolds, 2012). This could explain in part that those plots where severe water stress was applied, did not show significant differences in yield compared to well-watered cultivars, since water stress was imposed post-anthesis, and WSCs accumulated before anthesis could have contributed to the filling and growth of the grain. Furthermore, WSC concentration per stem at anthesis and maturity has shown large genotypic variability in different environments (del Pozo et al., 2016).

One of possible causes that yield obtained by wheat cultivars was not drastically influenced by severe water deficit may be due to the species root system. In this sense, as a drought tolerance strategy, plants develop a deep root system that allows the access to subsoil water $(20-100 \mathrm{~cm})$, achieving a better performance against a severe water stress (Daryanto et al., 2016). Besides, a report mentions that wheat can tolerate drought since it has a high osmotic adjustment, and together with high transpiration efficiency, allow the recovery of drought in the final stages of crop development (Daryanto et al., 2016). In a review where the response to drought was studied in 12 cultivated species, including wheat, a direct association was found between osmotic adjustment and yield (Blum, 2017). This is clear evidence on the relevance of osmotic adjustment as a physiological mechanism associated with the adaptation of crops to adverse conditions of water availability.

In this study, the average temperatures recorded for Chillán locality (Site 2), were between 0.5 and $1.3{ }^{\circ} \mathrm{C}$ higher than in Coihueco (Site 1), in the period between August and December 2016. In this way, environmental factors also affect wheat flour quality, for example the wheat gluten proteins which are a complex group of abundant proteins that are the major determinants of wheat flour quality can be affected by the environment where the crop is grown (Altenbach, 2012; Buenrostro-Rodríguez et al., 2019). Protein and gluten are not shown.

Antioxidant capacity in whole wheat flour is associated to its content of polyphenolic compounds, due to the presence of phenolic acids located in the outer layers of the wheat grain, where a major phenolic acids present is ferulic acid ( $\mathrm{Lv}$ et al., 2012; Andersson et al., 2014; Lu and Luthria, 2016). Values of total polyphenol contents detected in this research did not significantly differ $(\mathrm{P}>0.05)$ in relation to an increasing moisture deficit (well-watered to severe water deficit) differing only between cultivars (Table 5). The total polyphenol content in whole wheat flour samples was lower than those previously reported by Vaher et al. (2010) for wheat, who obtained values between 270 to $350 \mathrm{mg} \mathrm{GAE} 100 \mathrm{~g} \mathrm{~g}^{-1}$.

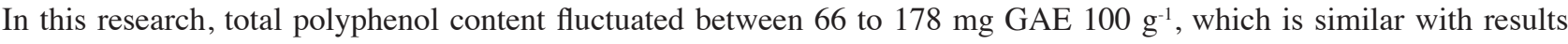
obtained by Lv et al. (2012), who obtained values between 166 and $201 \mathrm{mg} \mathrm{GAE} 100 \mathrm{~g} \mathrm{~g}^{-1}$ in whole wheat flour. Literature reports different total polyphenol contents in distinct parts of wheat grain. Furthermore, the use of different standards for total polyphenol content measurements makes the respective comparison quite difficult (Vaher et al., 2010).

In this study there was nonsignificant interaction between the three irrigation levels and four spring wheat cultivars studied on total polyphenols content in both locations. However, in Site 1 it was observed that moderate water deficit presented on average $17 \%$ and $19 \%$ higher values, compared to full irrigation and severe water deficit, respectively. While Site 2 recorded $6 \%$ and $13 \%$ higher values, compared to the irrigation levels of full irrigation and without irrigation, respectively. The above may be due to an environment influence since the grain composition is also affected by the climatic conditions of the environment where the crop is developed, especially temperature and water availability during 
grain development, as previously reported (Shewry, 2018). Furthermore, it has been reported that wheat cultivars under low input agricultural management have high levels of protein and polyphenols (Dinelli et al., 2013). Related to the above, it has been recently reported that wheat cultivars managed under a conventional cultivation system present higher values of protein and wet gluten, while the same cultivars managed under an organic production system present higher levels of total polyphenols and a greater antioxidant activity (Pandino et al., 2020). Nevertheless, previously several authors have reported that the total polyphenol content in wheat samples is closely related to the wheat genotype and milling procedure (Okarter et al., 2010; Liu et al., 2010; Vaher et al., 2010; Ivanisová et al., 2014). Fischer et al. (2013) explained that the differences in polyphenols contents in plants subjected to water stress could be by the irrigation cycles that they were exposed, since in their study they found differences in the content of total polyphenols in quinoa (Chenopodium quinoa Willd.) seeds. Despite to is also possible to find differences in the amount of polyphenols extracted from wheat bran, whole wheat flour and refined wheat flour, reporting values 4 and 25 times higher in wheat bran than whole wheat flour and refined, respectively (Lu and Luthria, 2016); the main phenolic compound present and determinant in the antioxidant power of wheat is ferulic acid (Lv et al., 2012; Andersson et al., 2014; Lu and Luthria, 2016).

Polyphenolic compounds are secondary metabolites synthesized by plants during its growth and are produced mostly in response to stress (Vaher et al., 2010). In this research, severe water deficit during grain filling stage did not show significant differences compared to level of moderate water deficit and without water deficit (well-watered), presenting a somewhat erratic response in general to relation to the total polyphenol content obtained from the whole wheat flour samples. The above may be mainly since in trials carried out under field conditions, there are other factors can stress the plant, and that at the field level cannot be well managed, such as light intensity and high temperatures (Lizana and Calderini, 2013; García et al., 2016). It is also important to note that the amount of polyphenols in cereals is variable depending on type of cereal, cultivar, if mill whole grain or bran, as well as the milling procedure (Adom et al., 2005).

Although there were nonsignificant differences on the yield, between well-watered and moderate water deficit treatments, in the four cultivars studied in both locations, it is necessary to analyze the response to water deficit, in trials involving several growing seasons and different environments. Studies are suggested that contemplate the analysis of soluble carbohydrates accumulated in the stem and also studies on the morphology and development of root system in wheat cultivars under water deficit, which allow complementing and understanding the behavior of different spring wheat cultivars subjected to a period of water deficit.

\section{CONCLUSIONS}

The water deficit level did not negatively influence the yield of the four wheat cultivars evaluated in Chillán (Site 2). While in Coihueco (Site 1), only the yield of 'Lasana' and 'Pantera-INIA CL' was reduced with severe water deficit level, without irrigation during grain filling stage.

The application of controlled water deficit in the stage between 50\% flowering and milky grain in wheat showed nonsignificant differences for the total polyphenol content in the four spring wheat cultivars studied, in both sites.

\section{ACKNOWLEDGEMENTS}

We would like to thank CONICYT for the financial support provided through the Advanced Human Capital Formation Program (2016 National Magister Scholarships). Also, thanks to the laboratory technical support provided from VITRA, for the samples analysis of whole wheat flour. In addition, we thank Dr. Iván Matus of INIA Quilamapu to provide us the seeds of the four wheat cultivars studied.

\section{REFERENCES}

Adom, K.K., Sorrells, M.E., and Liu, R.H. 2005. Phytochemicals and antioxidant activity of milled fractions of different wheat varieties. Journal of Agricultural and Food Chemistry 53(6):2297-2306.

Altenbach, S.B. 2012. New insights into the effects of high temperature, drought and post-anthesis fertilizer on wheat grain development. Journal of Cereal Science 56(1):39-50. https://doi.org/10.1016/j.jcs.2011.12.012. 
Andersson, A., Dimberg, L., Aman, P., and Landberg, R. 2014. Recent findings on certain bioactive components in whole grain wheat and rye. Journal of Cereal Science 59(3):294-311. https://doi.org/10.1016/j.jcs.2014.01.003.

Blum, A. 2017. Osmotic adjustment is a prime drought stress adaptive engine in support of plant production. Plant, Cell and Environment 40(1):4-10.

Buenrostro-Rodríguez, J.F., Solís-Moya, E., Gámez-Vázquez, A.J., Raya-Pérez, J.C., Mandujano-Bueno, A., Cervantes-Ortiz, F., et al. 2019. Yield performance and GGE biplot analysis of wheat genotypes under two irrigation treatments at El Bajio, Mexico. Chilean Journal of Agricultural Research 79:234-242. doi:10.4067/S0718-58392019000200234.

Daryanto, S., Wang, L., and Jacinthe, P.A. 2016. Global synthesis of drought effects on maize and wheat production. PLOS ONE 11(5): e0156362.

Del Pozo, A., y Del Canto, P. 1999. Areas agroclimáticas y sistemas productivos en la VII y VIII Regiones. Serie Quilamapu No 113. 116 p. Instituto de Investigaciones Agropecuarias (INIA), Chillán, Chile.

Del Pozo, A., Yáñez, A., Matus, I., Tapia, G., Castillo, D., Sanchez-Jardón, L., et al. 2016. Physiological traits associated with wheat yield potential and performance under water-stress in a Mediterranean environment. Frontiers in Plant Science 7:987.

Dinelli, G., Marotta, I., Di Silvestro, R., Bosi, S., Bregola, V., Accorsi, M., et al. 2013. Agronomic, nutritional and nutraceutical aspects of durum wheat (Triticum durum Desf.) genotypes under low input agricultural management. Italian Journal of Agronomy 8:85-93. https://doi.org/10.4081/ija.2013.e12

Engler, A., and del Pozo, A. 2013. Assessing long- and short-term trends in cereal yields: The case of Chile between 1929 and 2009. Ciencia e Investigación Agraria 40(1):55-67. https://doi.org/10.4067/S0718-16202013000100005.

Fahad, S., Bajwa, A.A., Nazir, U., Anjum, S.A., Farooq, A., Zohaib, A., et al. 2017. Crop production under drought and heat stress: Plant responses and management options. Frontiers in Plant Science 8:1147.

FAO. 2017. FAOSTAT Crops production database. Food and Agriculture Organization of the United Nations (FAO), Rome, Italy. Available at http://www.fao.org/faostat/en/\#data/QC (accessed 10 November 2017).

Farooq, M., Bramley, H., Palta, J.A., and Siddique, K.H. 2011. Heat stress in wheat during reproductive and grain-filling phases. Critical Reviews in Plant Sciences 30(6):491-507.

Fischer, S., Wilckens, R., Jara, J., and Aranda, M. 2013. Variation in antioxidant capacity of quinoa (Chenopodium quinoa Will) subjected to drought stress. Industrial Crops and Products 46:341-349.

García, G., Serrago, R.A., Dreccer, M.F., and Miralles, D.J. 2016. Post-anthesis warm nights reduce grain weight in field-grown wheat and barley. Field Crops Research 195:50-59. https://doi.org/10.1016/j.fcr.2016.06.002.

Hawkesford, M.J., Araus, J.L., Park, R., Calderini, D., Miralles, D., Shen, T., et al. 2013. Prospects of doubling global wheat yields. Food and Energy Security 2(1):34-48. https://doi.org/10.1002/fes3.15.

Hernandez, J., Lobos, G., Matus, I., del Pozo, A., Silva, P., and Galleguillos, M. 2015. Using ridge regression models to estimate grain yield from field spectral data in bread wheat (Triticum aestivum L.) grown under three water regimes. Remote Sensing 7(2):2109-2126. https://doi.org/10.3390/rs70202109.

Hussain, S., Khaliq, A., Bajwa, A.A., Matloob, A., Areeb, A., Ashraf, U., et al. 2017. Crop growth and yield losses in wheat due to little seed canary grass infestation differ with weed densities and changes in environment. Planta Daninha 35:e017162328.

Ivanisová, E., Ondrejovic, M., Chmelová, D., Maliar, T., Havrlentová, M., and Rückschloss, L. 2014. Antioxidant activity and polyphenol content in milling fractions of purple wheat. Cereal Research Communications 42(4):578588. https://doi.org/10.1556/CRC.2014.0008.

Kim, M.J., and Kim, S. 2017. Utilisation of immature wheat flour as an alternative flour with antioxidant activity and consumer perception on its baked product. Food Chemistry 232:237-244. https://doi.org/10.1016/j.foodchem.2017.04.007.

Liu, Q., Qiu, Y., and Beta, T. 2010. Comparison of antioxidant activities of different colored wheat grains and analysis of phenolic compounds. Journal of Agricultural and Food Chemistry 58(16):9235-9241. https://doi.org/10.1021/jf101700s.

Lizana, X.C., and Calderini, D.F. 2013. Yield and grain quality of wheat in response to increased temperatures at key periods for grain number and grain weight determination: Considerations for the climatic change scenarios of Chile. Journal of Agricultural Science 151(2):209-221. https://doi.org/10.1017/S0021859612000639.

Lobo, V., Patil, A., Phatak, A., and Chandra, N. 2010. Free radicals, antioxidants and functional foods: impact on human health. Pharmacognosy Reviews 4(8):118-126. https://doi.org/10.4103/0973-7847.70902.

Lopes, M.S., and Reynolds, M.P. 2012. Stay-green in spring wheat can be determined by spectral reflectance measurements (normalized difference vegetation index) independently from phenology. Journal of Experimental Botany 63(10):3789-3798.

Lu, Y., and Luthria, D. 2016. Influence of gelatinization on the extraction of phenolic acids from wheat fractions. Food Chemistry 194:1138-1142.

Lv, J., Yu, L., Lu, Y., Niu, Y., Liu, L., Costa, J., et al. 2012. Phytochemical compositions, and antioxidant properties, and antiproliferative activities of wheat flour. Food Chemistry 135(2):325-331. https://doi.org/10.1016/j.foodchem.2012.04.141.

Ma, D., Sun, D., Wang, C., Li, Y., and Guo, T. 2014. Expression of flavonoid biosynthesis genes and accumulation of flavonoid in wheat leaves in response to drought stress. Plant Physiology and Biochemistry 80:60-66. https://doi.org/10.1016/j.plaphy.2014.03.024.

Mäkinen, H., Kaseva, J., Trnka, M., Balek, J., Kersebaum, K.C., Nendel, C., et al. 2018. Sensitivity of European wheat to extreme weather. Field Crops Research 222:209-217. https://doi.org/10.1016/j.fcr.2017.11.008. 
Mellado, M. 2007. El trigo en Chile. Colección Libros INIA N²1. 684 p. Instituto de Investigaciones Agropecuarias (INIA), Chillán, Chile.

ODEPA. 2017. Estadísticas productivas, estadísticas de cultivos. Información nacional de superficie sembrada, producción y rendimientos anuales. Oficina de Estudios y Políticas Agrarias (ODEPA). Ministerio de Agricultura, Santiago, Chile. Available at https://www.odepa.gob.cl/estadisticas-del-sector/estadisticas-productivas (accessed August 2017).

Okarter, N., Liu, C.S., Sorrells, M.E., and Liu, R.H. 2010. Phytochemical content and antioxidant activity of six diverse varieties of whole wheat. Food Chemistry 119(1):249-57. https://doi.org/10.1016/j.foodchem.2009.06.021.

Pandino, G., Mattiolo, E., Lombardo, S., Lombardo, G.M., and Mauromicale, G. 2020. Organic cropping system affects grain chemical composition, rheological and agronomic performance of durum wheat. Agriculture 10:46. https://doi.org /10.3390/agriculture10020046.

Poutanen, K. 2012. Past and future of cereal grains as food for health. Trends in Food Science and Technology 25(2):58-62. https://doi.org/10.1016/j.tifs.2012.02.003.

Rajala, A., Hakala, K., Mäkelä, P., Muurinen, S., and Peltonen-Sainio, P. 2009. Spring wheat response to timing of water deficit through sink and grain filling capacity. Field Crops Research 114(2):263-271.

Rajala, A., Hakala, K., Mäkelä, P., and Peltonen-Sainio, P. 2011. Drought effect on grain number and grain weight at spike and spikelet level in six-row spring barley. Journal of Agronomy and Crop Science 197(2):103-112.

Saint Pierre, C., Peterson, C.J., Ross, A.S., Ohm, J.B., Verhoeven, M.C., Larson, M., et al. 2008. Winter wheat genotypes under different levels of nitrogen and water stress: Changes in grain protein composition. Journal of Cereal Science 47(3):407-416. https://doi.org/10.1016/j.jcs.2007.05.007.

Shewry, P.R. 2018. Do ancient types of wheat have health benefits compared with modern bread wheat? Journal of Cereal Science 79:469-476. https://doi.org/10.1016/j.jcs.2017.11.010.

Stolpe, N. 2011. Conservación de suelos. $2^{a}$ ed. Departamento de Suelos y Recursos Naturales, Facultad de Agronomía, Universidad de Concepción, Chillán, Chile.

Vaher, M., Matso, K., Levandi, T., Helmja, K., and Kaljurand, M. 2010. Phenolic compounds and the antioxidant activity of the bran, flour and whole grain of different wheat varieties. Procedia Chemistry 2(1):76-82.

Zadoks, J.C., Chang, T.T., and Konzak, C.F. 1974. A decimal code for the growth stages of cereals. Weed Research 14(14):415-421.

Zhang,Y.,Yu,Z.,Shi,Y.,Gu,S., and Zhang Y.2019. Effects of supplemental irrigation based on soil water content on water consumption, dry matter and yield of wheat. Chilean Journal of Agricultural Research 79:190-201 doi:10.4067/S0718-58392019000200190. 